JASEM ISSN 1119-8362

All rights reserved
Full-text Available Online at www.bioline.org.br/ja
J. Appl. Sci. Environ. Manage. June, 2007

Vol. 11 (2) $\underline{201-\underline{208}}$

\title{
Physico-chemical, mineralogical and chemical considerations in understanding the 2001 Mabeta New Layout landslide, Cameroon
}

\section{${ }^{* 1}$ NGOLE, VERONICA M; ${ }^{2}$ GEORGES-IVO E. EKOSSE; ${ }^{3}$ AYONGHE, SAMUEL N}

\author{
${ }^{1}$ Department of Geography, Environmental Science and Planning, University of Swaziland, Private Bag 4 Kwaluseni M201, Swaziland \\ ${ }^{2}$ Department of Geology, Mining and Minerals, University of Limpopo, P/BagX1106 Sovenga 0727 Limpopo Province, South Africa \\ ${ }^{3}$ Department of Geology and Environmental Science, Faculty of Science, University of Buea, P.O. Box 63, Buea, Cameroon.
}

\begin{abstract}
Landslides are part of natural catastrophic disasters destroying both biological and physical entities including loss of human lives. An evaluation of soil properties involved in landslides is significant in its management. To this effect, soil samples from the 2001 landslide occurrences in the Mabeta New Layout, Limbe, Cameroon were analysed using standard techniques to determine texture, $\mathrm{pH}$, electrical conductivity (EC), bulk density $\left(\mathrm{D}_{b}\right)$, water absorption percent (WA), linear shrinkage, plasticity index (PI), loss-on-ignition (LOI), mineral content and major cations. Results obtained were: bulk density $\left(0.89-1.08 \mathrm{~g} / \mathrm{cm}^{3}\right)$, LOI $(19.4-25.7 \%)$, water absorption (23.4 - 29.1\%), linear shrinkage (5.4 - 8.3\%), volume shrinkage $(4.8-8.5 \%)$, PI (13.5 $20.75 \%)$, major cations $\left(\left(\mathrm{Fe}_{2} \mathrm{O}_{3}: 9.91-23.24 \%\right),\left(\mathrm{Al}_{2} \mathrm{O}_{3}: 9.88-28.48 \%\right),(\mathrm{CaO}: 0.73-1.3 \%),(\mathrm{MgO}: 0.55-\right.$ $\left.2.80 \%),\left(\mathrm{K}_{2} \mathrm{O}: 1.06-1.59 \%\right),\left(\mathrm{Na}_{2} \mathrm{O}: 0.77-0.89 \%\right)\right), \mathrm{pH}(5.17-6.90)$ and $\mathrm{EC}(16.53-149.20 \mu \mathrm{S} / \mathrm{cm})$. Values from physico-chemical analyses, secondary minerals abundance index (SMAI) and chemical index of alteration (CIA) of the soils were reflective of particles with high potential for sliding. With major contributions from favourable slope, seismic and hydrologic forces, the event occurred. @JASEM
\end{abstract}

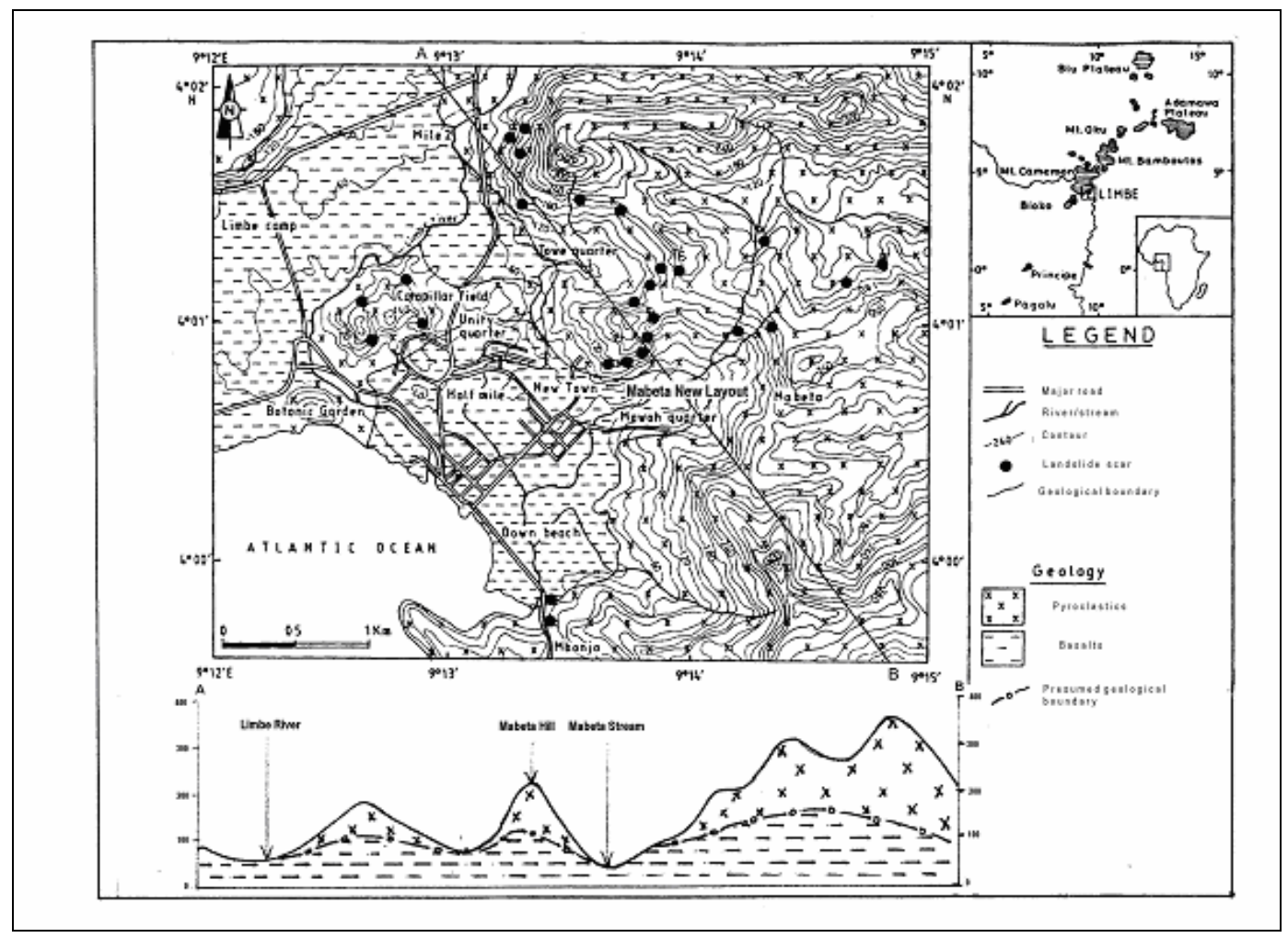

Fig 1: Map of the study area showing its geology, hydrology and location of landslide scars, and geological cross-section (adopted from Ekosse et. al., 2005) 
The occurrence of natural disasters has caused the loss of millions of lives in recent years especially in developing countries which are less equipped technically and financially to handle such disasters. These catastrophic events include floods, tsunamis, earthquakes, eruptions, lacustrine degasifications, mudflows and landslides. One of the countries hard hit by these natural disasters is Cameroon. The Cameroon Volcanic Line (CVL) (Fig 1) has in recent years been plagued by a series of natural disasters which include volcanic eruptions, earth quakes and tremors (Suh et al., 2003) degasification of volcanic lakes and maars (Ekosse 1998; Kusakabe et al., 1989; and Kanari, 1989) and landslides (Mcknight, 1992). Of all these disasters, the most frequent has been landslides (Ayonghe et al., 2002). Ekosse et al., (2005) reported over 100 landslides along the CVL between 1988 and 2001. The Mabeta New Layout landslide of 2001 adds to the number of landslide events that have occurred along the volcanic line (Ayonghe et al., 2002).

The site for the 2001 landslide event is Mabeta New Layout, which is situated in Limbe (Fig 1); a coastal town on the south eastern side of Mount Cameroon. This area comprises part of the CVL which is over $1600 \mathrm{~km}$ long, stretching from Pagalu to Oku via Sao Tome Principe, and Bioko, Limbe (Ekosse et al., 2005; Fitton and Dunlop, 1985). The rocks of the CVL range in composition from picro-basalt and basalt through intermediate compositions to phonolite and rhyolite. Marzoli et al., (2000) have characterized the geology of the CVL. The parent material of the unconsolidated sediments along the CVL, and particularly those of Mount Cameroon have been petrochemically characterised by Suh et al., (2003). The soils around the area have been derived from weathering of the volcanic cones and are characterised by interlayers of volcanic ash and blocky lava (Ekosse et al., 2005). They are immature with no distinct horizon. Details of the soil types and geomorphology around Limbe are documented in Ekosse et al., (2005) Fonge et al., (2005) and SamaLang (2004). The landscape is undulating in nature with an altitude which ranges from zero at the shore of the Atlantic Ocean to a chain of horse - shoe hills towards the study area. Streams which eventually discharge into the Atlantic Ocean traverse the landscape. The climate is tropical with mainly two distinct seasons; a rainy season between April and September and a dry season from October to March.
Rainfall received in the area varies from 2085 - 9086 mm (Fonge et al., 2005).

The physico-chemistry, mineralogy and geochemistry of sediments, as well as external forces such as climate and anthropogenic activities influence causes and patterns of landslides. According to Ayonghe et al., (2002) the causes of the landslides along the CVL were of hydrological, seismic and tectonic origins. Whereas the greatest blame of most landslide events rests on rainfall (Shaw-Shong 2004), there are several underlying factors that may render slopes susceptible to slides. A recent study by Ekosse et. al. (2005) on landslide activities along the CVL, examined the mineralogical composition of the unconsolidated surface sediments from the different scars at the site of the 2001 Mabeta landslide event. The work did not consider possible findings from physico-chemical and geochemical analyses as other significant contributing factors to the Mabeta landslide event. Moreover, no study has looked at how heterogeneities brought about by chemical alteration of the primary minerals in the material that constitute the soils at the site of the landslide may have contributed to the occurrence of the events at Mabeta New Layout. This study therefore focused on the role played by chemical alteration in the creation of field heterogeneities and how they may have contributed to the landslide events of March 2001 at Mabeta New Layout, Limbe.

\section{MATERIALS AND METHODS}

Samples collection: Using judgemental sampling technique (Crépin et. al., 1993), 13 soil samples were collected from three different areas where the 2001 Mabeta landslide event occurred. The three different sites were geographically located at longitude $9^{\circ} 13^{\prime}$ $19^{\prime}$ ' E, latitude $4^{\circ} 00^{\prime} 43^{\prime \prime}$ N (labelled A), longitude $9^{\circ} 13^{\prime} 23^{\prime \prime}$ E, latitude $4^{\circ} 00^{\prime} 44^{\prime \prime} \mathrm{N}$ (labelled B), and longitude $9^{\circ} 13^{\prime} 45^{\prime}$ ' E, latitude $4^{\circ} 00^{\prime} 52^{\prime \prime} \mathrm{N}$ (labelled C) respectively (Fig 2). Six samples were collected from site A, four samples from site B and three samples from site $\mathrm{C}$. The 13 samples were collected at depths of between 0 and $20 \mathrm{~cm}$ at the slide surface. The hue/value/chroma of the soils ranged from $5 \mathrm{YR} / 5 / 3$ to $5 \mathrm{YR} / 4 / 6$ to $5 \mathrm{YR} / 3 / 4$ with corresponding colour shades from reddish-brown to yellowish-red to dark reddish-brown (Ekosse et. al. (2005).All samples were air - dried, sieved to remove gravel and packaged for analyses. 


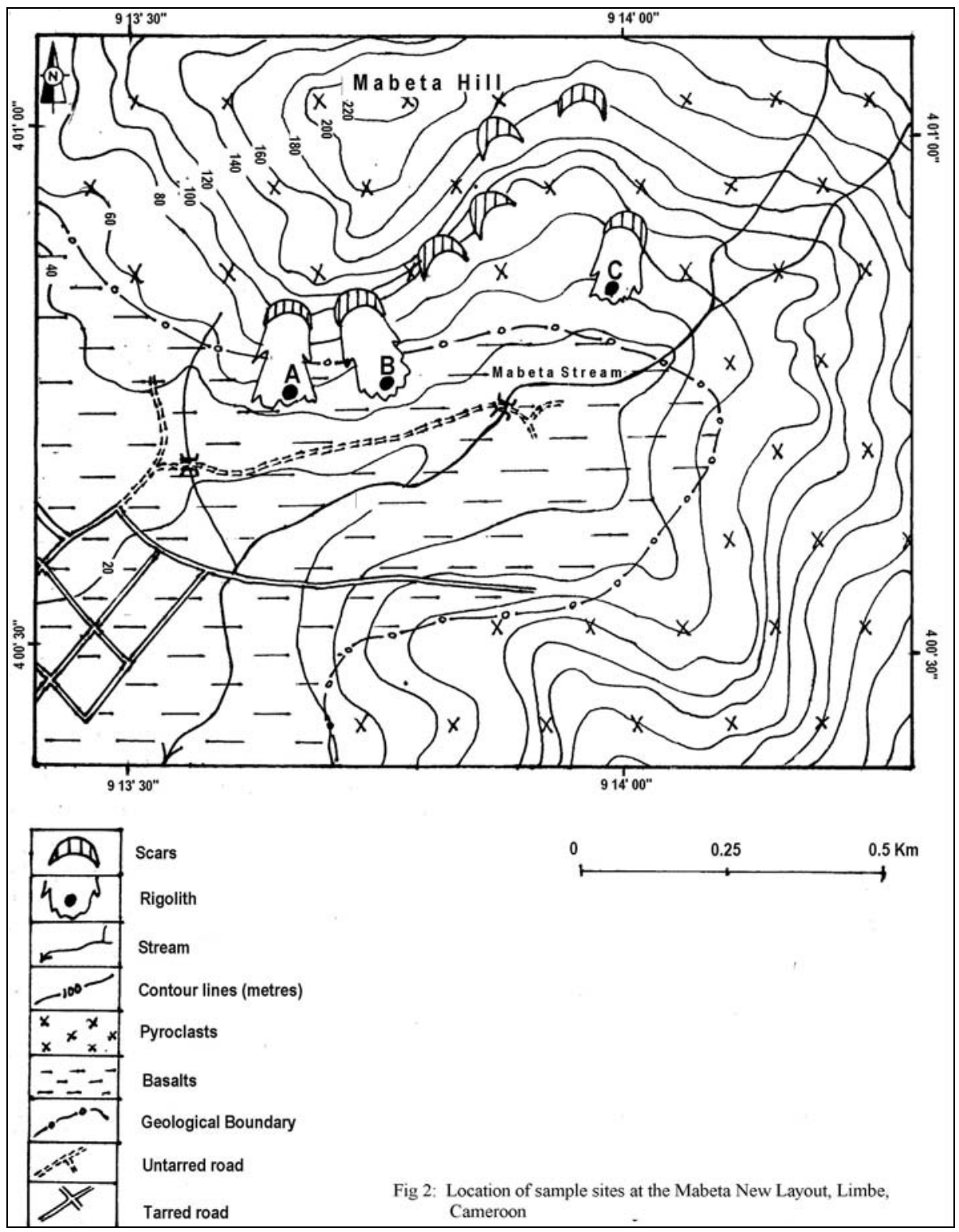

Fig 2: Map of Mabeta New Layout showing its geology, scars, regolith and sample sites (adopted from Ekosse et. al., 2005)

Laboratory analyses: Parameters analyzed for in the different soil samples included texture, $\mathrm{pH}$, electrical conductivity (EC), bulk density $\left(\mathrm{D}_{b}\right)$, water absorption percent (WA), linear shrinkage, percent loss-on-ignition (LOI) and major cations including $\mathrm{Fe}, \mathrm{Al}, \mathrm{Ca}, \mathrm{Mg}, \mathrm{Na}, \mathrm{K}$. To obtain values for linear and volume shrinkage, WA, and LOI of the samples, methods described in ASTM (1993), Shi et al., (2005), Forster, (1995), and Heiri et al., (2001) were employed. The plasticity index (PI) was estimated from the linear shrinkage values obtained (Jackson, 2001). The texture of the samples was determined using the hydrometer method as described in Van Reeuwijk (1993). The $\mathrm{pH}$ and EC were determined in a 1: 2.5 soil water suspension of each sample, as described by Palumbo et al., (2000), whereas the method for $\mathrm{D}_{b}$ determination of disturbed soil described in Tan (1996) was used to determine the $\mathrm{D}_{b}$ of the different samples. For the extraction of major cations, the procedure described by Tokalioğlu et al., (2003) was employed. Determination of cations in the sample extracts was done using a SpectrAA Varian $220 \mathrm{FS}$ flame atomic absorption spectrometer with deuterium correction.

\section{RESULTS AND DISCUSSION}

In terms of particle size distribution, the weight percent (wt \%) of fine sand + silt + clay of the samples was higher than the values of coarse sand in each sample (Table 1). Samples from site A had a relatively higher bulk density that those from either site B or C (Table 1). Samples from site B had higher 
values for both linear and volume shrinkage than those from sites $\mathrm{A}$ and $\mathrm{B}$ as indicated in Table 1. Values for LOI and WA were higher for samples from site $\mathrm{C}$ than samples from site $\mathrm{A}$ and $\mathrm{B}$. The mean values for PI of the soil samples ranged from $13.5 \%$ at site $\mathrm{A}$ to $20.75 \%$ at site $\mathrm{C}$. The values obtained for $\mathrm{pH}$ and $\mathrm{EC}$ indicated that samples from site $\mathrm{B}$ and $\mathrm{C}$ were slightly acidic with low amounts of dissolved salts (Table 2). Samples from site B and C also had higher values for the concentration of oxides of $\mathrm{Fe}$ and $\mathrm{Al}$ whereas the values for $\mathrm{Na}_{2} \mathrm{O}$ were similar for all three sites (Table 2). Among the oxides of the base elements, the values for $\mathrm{MgO}$ were the highest (Table 2).
Table 1: Physico-chemical properties of soil samples of the 2001 landslides at the Mabeta New Layout area

\begin{tabular}{lccc}
\hline Properties & Site & Site & Site \\
& $\mathrm{A}$ & $\mathrm{B}$ & $\mathrm{C}$ \\
\hline Fine sand + silt+ clay wt \% & 53.6 & 67.0 & 54.3 \\
Medium + coarse sand wt \% & 27 & 31 & 44.7 \\
Bulk density $\left(\mathrm{g} / \mathrm{cm}^{3}\right)$ & 1.08 & 0.97 & 0.89 \\
Loss-on-ignition (\%) & 24.1 & 19.4 & 25.7 \\
Water absorption (\%) & 24.5 & 29.1 & 23.4 \\
Linear shrinkage (\%) & 5.4 & 8.3 & 7.7 \\
Volume shrinkage (\%) & 4.8 & 8.5 & 7.0 \\
\hline Plasticity index (\%) & 13.5 & 20.75 & 19.25 \\
\hline
\end{tabular}

Table 2: Elemental concentrations, $\mathrm{pH}$ and electrical conductivity of soil samples of the 2001 landslides at the Mabeta New Layout area

\begin{tabular}{lcccccccc}
\hline & $\mathrm{Fe}_{2} \mathrm{O}_{3}$ & $\mathrm{Al}_{2} \mathrm{O}_{3}$ & $\mathrm{CaO}$ & $\mathrm{MgO}$ & $\mathrm{K}_{2} \mathrm{O}$ & $\mathrm{Na}_{2} \mathrm{O}$ & $\mathrm{pH}$ & $\mathrm{EC}(\mu \mathrm{S} / \mathrm{cm})$ \\
$\mathrm{SA} 1$ & 10.17 & 13.98 & 0.95 & 2.38 & 1.17 & 0.81 & 6.59 & 78.31 \\
$\mathrm{SA} 2$ & 20.01 & 24.61 & 0.81 & 0.75 & 1.10 & 0.81 & 5.57 & 30.66 \\
$\mathrm{SA} 3$ & 9.91 & 15.36 & 1.30 & 2.38 & 1.59 & 0.89 & 5.94 & 65.50 \\
$\mathrm{SA} 4$ & 10.76 & 11.86 & 0.98 & 2.17 & 1.46 & 0.80 & 6.90 & 85.30 \\
$\mathrm{SA6}$ & 11.33 & 11.14 & 1.01 & 2.80 & 1.45 & 0.77 & 6.68 & 96.52 \\
$\mathrm{SA6}$ & 14.61 & 9.88 & 1.13 & 2.43 & 1.46 & 0.80 & 6.81 & 149.20 \\
$\mathrm{SB} 1$ & 19.89 & 26.31 & 0.73 & 0.55 & 1.13 & 0.78 & 5.17 & 19.26 \\
$\mathrm{SB} 2$ & 23.24 & 24.12 & 0.77 & 0.90 & 1.08 & 0.77 & 5.48 & 16.53 \\
$\mathrm{SB} 3$ & 22.46 & 28.48 & 0.85 & 0.67 & 1.06 & 0.77 & 5.46 & 29.00 \\
$\mathrm{SC} 1$ & 21.94 & 26.14 & 0.92 & 0.83 & 1.31 & 0.81 & 5.67 & 21.00 \\
$\mathrm{SC} 2$ & 19.79 & 26.82 & 0.90 & 0.75 & 1.12 & 0.80 & 5.75 & 18.90 \\
\hline
\end{tabular}

Physico-chemical considerations: Though landslides usually occur at the permeability barrier between the slip zone of the Mabeta New Layout landslide event must have developed within the thick lateritic profiles characteristic of these soils as a result of heterogeneities brought about by weathering. The higher wt $\%$ of finer particles indicates that weathering in the Mabeta New Layout environment is advanced a fact which is justified by the values obtained for LOI of the samples. According to Tugrul and Gurpinar, (1997) and Kim \& Park, (2003), values for LOI decrease with the progress of potential weathering in basalts and metamorphic rocks.

Accumulation of finer particles in the profiles may have resulted in slow infiltration rates with a consequent increase in water content as reflected by the values of water absorption. This resulted in fluctuations in $\mathrm{D}_{b}$ as indicated by the values for Plasticity Index (PI). The greater the PI, the more plastic and compressible the unconsolidated sediments, and the greater its volume change characteristics. Changes in volume of the soils and the bedrock (Crosta et al., 2003), bedrock was not exposed at any of the landslide scars. The unconsolidated sediments would increase the disturbance on the slopes which already had their angle of repose disturbed by the expanded development of the area. The gradient of the slopes of the volcanic cones at Mabeta New Layout according to Ayonghe et al., (2002) are between $40^{\circ}$ and $80^{\circ}$. This angle is steeper than the angle of repose of most rocks as stated in Smithson et al., (2002). Any activity that disturbs these slopes is therefore likely to result in sliding.

Mineralogical considerations: The mineralogical composition of the unconsolidated sediments from the scars of the Mabeta landslide events have been documented in Ekosse et al., (2005). The saprolite of the sediments from the Mabeta landslide scars consists mainly of clinopyroxene $\left(\mathrm{Ca}(\mathrm{TiMgAl})(\mathrm{SiAl})_{2} \mathrm{O}_{6}\right)$, hematite $\left(\alpha-\mathrm{Fe}_{2} \mathrm{O}_{3}\right)$ and goethite $(\alpha-\mathrm{FeO} . \mathrm{OH})$, whereas the soils consists 
mainly of anatase $\left(\mathrm{TiO}_{2}\right)$, annite $\left(\mathrm{KFe}_{3} \mathrm{AlSiO}_{10}(\mathrm{OH}, \mathrm{F})_{2}\right)$, augite $\left(\mathrm{Ca}_{2}(\mathrm{Al}-\mathrm{Fe})_{4}(\mathrm{Mg}-\right.$ $\left.\mathrm{Fe})_{4} \mathrm{Si}_{6} \mathrm{O}_{24}\right)$, goethite, hematite and kaolinitic minerals $\left(\mathrm{Al}_{2} \mathrm{Si}_{2} \mathrm{O}_{5}(\mathrm{OH})_{4}\right)$ (Ekosse et al., (2005). These minerals are usually found in basaltic material which forms the parent material from which the soils were derived. Excessive leaching of $\mathrm{Mg}, \mathrm{Ca}, \mathrm{K}$, and $\mathrm{Na}$ caused by the high rainfall in the area results in the synthesis of goethite and kaolinite in addition to the hematite identified in the finer fraction $(<4 \mu \mathrm{m})$ of the samples.

Using results of the semi quantitative summary of the minerals identified in the various samples as reported in Ekosse et al., (2005) and their hardness, the secondary minerals abundance index (SMAI) was determined by multiplying the relative quantities with the hardness of the various minerals and comparing with what would have been if there was complete crystallization of the minerals. The assumption is that if the minerals are well crystallized, they would all appear as major rather than minor or trace as reported by Ekosse et al., (2005). Secondary minerals are more likely to be abundant where weathering is advanced and minerals high on the Mohr Scale of Hardness are less likely to be weathered. The degree of hardness and weathering are therefore controlling factors in secondary mineral abundances. Higher SMAI values infer abundance of secondary minerals thereby depicting intense alteration, more fine particles and a higher probability of their sliding. All three sites showed relatively high degree of mineralization of secondary minerals (Table 3) indicating advanced weathering of the basalts.

Table 3: Degree of crystallization of secondary minerals in the different samples

\begin{tabular}{|c|c|c|c|c|c|c|c|c|c|c|}
\hline $\begin{array}{l}\text { Sample } \\
\text { ID }\end{array}$ & AN & $\mathrm{AE}$ & MG & GT & HT & $\mathrm{KN}$ & OBS & EXS & SMAI & MEAN \\
\hline SA1 & & & 6 & & 18 & & 24 & 36 & 66.67 & 79.63 \\
\hline SA2 & & 3 & & & 18 & & 21 & 27 & 77.78 & \\
\hline SA3 & & 3 & & & 18 & & 21 & 27 & 77.78 & \\
\hline SA4 & & 3 & & & 18 & & 21 & 27 & 77.78 & \\
\hline SA5 & & & & & 18 & & 18 & 18 & 100.00 & \\
\hline SA6 & & 3 & & & 18 & & 21 & 27 & 77.78 & \\
\hline SB1 & 12 & & & 11 & 18 & & 41 & 52.5 & 78.10 & 76.39 \\
\hline SB2 & & 3 & 6 & & 18 & 4 & 31 & 51 & 60.78 & \\
\hline SB3 & & & & 16.5 & 12 & & 28.5 & 34.5 & 82.61 & \\
\hline SB4 & & & & 11 & 18 & & 29 & 34.5 & 84.06 & \\
\hline $\mathrm{SC} 1$ & & & & 16.5 & 12 & 2 & 30.5 & 40.5 & 75.31 & 76.53 \\
\hline $\mathrm{SC} 2$ & & & & 16.5 & & & 16.5 & 16.5 & 100.00 & \\
\hline $\mathrm{SC} 3$ & & & 6 & 16.5 & 6 & & 28.5 & 52.5 & 54.29 & \\
\hline Saprolit & & & & 11 & 12 & 2 & 25 & 40.5 & 61.73 & 61.73 \\
\hline
\end{tabular}

Note: $\overline{\mathrm{e}} \overline{A N}=$ anatase, $A E=$ annite, $M G=$ magnetite, $H T=$ hematite, $G T=$ goethite, $K N=$ kaolinitic mineral, $O B S=$ observed sum, EXS $=$ expected sum, $S M A I=$ secondary minerals abundance index

Chemical considerations: Chemical Index of Alteration (CIA) proposed by Nesbitt and Young (1982) could be used to study the degree of alteration of sediments (Ericksson et. al., 1990). It is based on the equation

$\mathrm{CIA}=100 \mathrm{X} \mathrm{Al}_{2} \mathrm{O}_{3} /\left(\mathrm{Al}_{2} \mathrm{O}_{3}+\mathrm{CaO}+\mathrm{Na}_{2} \mathrm{O}+\mathrm{K}_{2} \mathrm{O}\right)(1)$

Although there are many mineral phases occurring in the sample analysed, each of the mineral phase in this study is considered an independent entity. In complete weathering, CIA is $100 \%$ due to the fact that ions of $\mathrm{Ca}, \mathrm{Na}$ and $\mathrm{K}$ are very mobile. According to Nesbitt \& Wilson (1982), CIA values for clinopyroxene is 20, whereas that of kaolinite, gibbsite and other secondary mineral is 100 . The average upper continental crust has a CIA value of 50 (Taylor and McLennan, 1985). The values for CIA obtained for the Mabeta samples were between 74.47 and 91.39 being close to 100 (Fig 3) which indicated a shift from primary to secondary minerals. Alteration of primary minerals to secondary minerals as weathering progresses results in an increase in the CIA values as a result of a decrease in primary mineral content and accumulation of secondary minerals (Nesbitt \& Wilson, 1992). This was also observed in the soil samples from the Mabeta landslide surface. Alteration is usually accompanied by the leaching of the soluble bases $\mathrm{Ca}, \mathrm{Na}$, and $\mathrm{K}$, from the mineral complex leaving behind acidic aluminous phases as reflected by values for the sample $\mathrm{pH}$. 


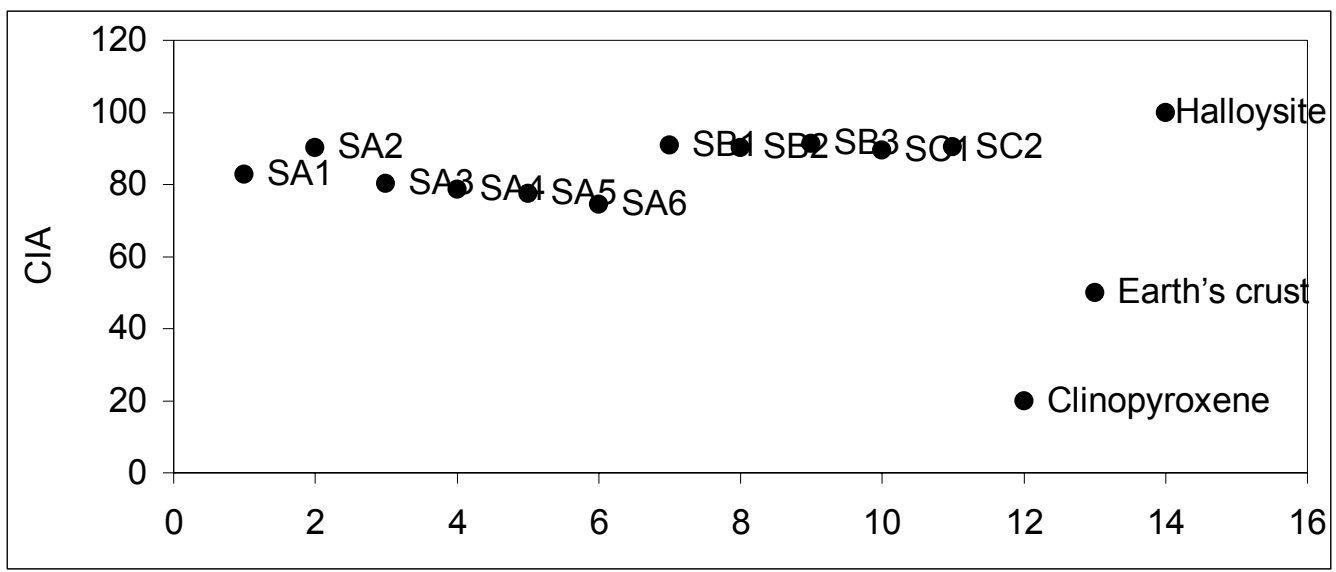

Fig 3: Chemical alteration index of samples as well as minerals identified in the samples

Integrated aspects for Mabeta landslide occurrence: The minerals identified in the soils from the landslide scar are reflective of the intensive weathering that has taken place within the Mabeta New Layout. Intense weathering leads to mineralogical, petrographical, and geochemical heterogeneities depending on the geological setting (Duzgoren-Aydin \& Aydin, 2006; Aydin, 2006). Heterogeneities may result in sudden and substantial changes in weathering signatures, and a consequent change in mechanical and hydraulic characteristics such as leaching and pore water pressures rendering the slopes susceptible to slides. According to Nesbitt and Wilson, (1992) oxides, hydroxides and oxyhydroxides of $\mathrm{Al}, \mathrm{Fe}$ and $\mathrm{Ti}$ dominate the mineralogy of intensively weathered profiles. Accumulation of oxyhydroxides in these profiles may affect the pore water pressure. Pore water pressure would also be compounded by the finer particles which have the ability to retain water. High water retention in the soils is most likely to reduce the matric suction of the soil particles causing a decrease in its shear strength and consequently an increase in the likelihood of landslides (Huat et. al., 2005). Similar observations have been made by Kirk et al., (1997) and are further supported by the fact that the slip zones and detachment surfaces of most landslides in tropical and subtropical settings are partly or completely delineated by persistent heterogeneities (Wen et al., 2004; Duzgoren-Aydin \& Aydin, 2006; Aydin 2006).

Physico-chemical data obtained and particularly that for PI were supportive of sediment sliding. Results obtained for SMAI and CIA of samples both reflect environment of intense weathering. Weathering pattern reflects mineralogical, petrographical, and geochemical heterogeneities due to sharp slope gliding/lubricating slopes, and geological setting of altered sediments. Although hydrologic, tectonic and seismic factors were key players in the triggering of the landslide, other major factors included physico- chemical properties, mineral assemblages and their characteristics, and chemical compositions of the unconsolidated sediments. Therefore, the physicochemical, mineralogical and chemical considerations must be taken into account in interpreting the causes of the 2001 Mabeta New Layout landslide.

\section{REFERENCES}

American Society for testing and Materials (1993). Annual Book of ASTM standards. Construction, Section 4. soil and rock ; dimension stone; geosynthesis. Vol 04.08. Philadelphia

Aydin, A (2006). Stability of saprolitic slopes: nature and role of field scale heterogeneities. Natural Hazards and Earth System Sciences. 6: 89-96.

Ayonghe, S. N., Suh, C. E., Ntasin, E. B., Samalano, P., and Fantong, W., (2002). Hydrologically siesmically and tecntonically triggered landslides along the Cameroon Volcanic Line, Cameroon. African Geosciences Review, 9: 325 - 335.

Crépin J and Johnson R.L. (1993) Soil sampling for environmental assessment. In Carter R. M. (Ed) Soil sampling and methods of analyses (Boca Raton, Fl: Lewis Publishers)

Crosta, G. B., Dal Negro, P., and Frattini, P. (2003). Soil slips and debris flows on terraced slopes. Natural Hazards and Earth System Sciences. 3: $31-42$

Duzgoren-Aydin, N. S. and Aydin, A. (2006). Chemical and mineralogical heterogeneities of weathered igneous profiles: implications for landslide investigations. Natural hazards and Earth System Sciences. 6: $315-322$.

Ekosse G. (1997/98). The potential role of organic matter as a secondary source of sedimentary 
gases produced in the volcano-lacustrine environment of Lake Nyos Maar, Cameroon. Journal of African Research and Development $27 \& 28,228-236$

Ekosse G., Ngole V., Sendze Y., and Ayonghe S. (2005). Environmental mineralogy of unconsolidated surface sediments associated with the 2001 landslides on volcanic cones, Mabeta New Layout, Limbe, Cameroon. Global Journal of Environmental Science 4(2) 115 - 122

Ericksson P. G., Twist D., Snyman C. P. and Burger L. (1990) The geochemistry of the Silverton Shale Formation, Transvaal Sequence. South African Journal of Geology 93, 454-462

Fitton, J. G., and Dunlop, H., (1985). The Cameroon Line, West Africa and its bearing on the origin of oceanic and continental basalt. Earth Planetary Science Letters. 72: $23-38$.

Fonge B. A. Yinda G.S., Focho D.A., Fongod A.G.N.1 and Bussmann R.W., (2005) Vegetation and soil status on an 80 year old lava flow of Mt. Cameroon, West Africa. Lyonia 8(1) $19-41$.

Forster, J. C. (1995). Soil Physical Analyses. In Alef $\mathrm{K}$ and Nannipieri (Eds), Methods of Applied Soil Microbiology and Biochemistry. Academic Press, London.

Gibbs R. J. (1984) Settling velocity, diameter and density for flocs of illite, kaolinite and montmorillonite. Journal of Sedimentary Petrology 55, $65-68$

Heiri, O., Lotter, A. F., and Lemcke, G (2001). Loss on ignition as a method for estimating organic and carbonate content in sediments: reproducibility and comparability of results. Journal of Paleolimnology 25: 101-110.

Huat, B. B. K., Ali, F and Mariappan S. (2005) Effect of surface cover on water infiltration rate and stability of cut slope in residual soils. Electronic Journal of Geotechnical Engineering 10 (G) 0614

Jackson, B., (2001) Atterberg limits. Background to Matereials Engineering Manual. Http:/www.mite.com.au/manual/p6a.html

Kanari, S., (1989).An inference on the process of gas outburst from Lake Nyos, Cameroon. Journal of Volcanology and Geothermal Research, 39(2-3) : 135-149.
Kim, S. and Park, H-D. (2003). The relationship between physical and chemical weathering indices of granites around Seoul, Korea. Bulletin of Engineering Geology and the Environment. 62: $207-212$.

Kirk P. A., Campbell, S. D. G, Fletcher, C. J. N., and Merriman, R. J (1997). The significance of primary volcanic fabrics and clay distribution in landslides in Hong

Marzoli, A., Piccirillo, E. M., Renne, P. R., Belilieni, G., Lacumin, M., Nyobe, J. B., and Tongwa, A. T., (2000). The Cameroon Volcanic Line revisited: Petrogénesis of continental basaltic magmas from lithospheric mantle sources. Journal of Petrology, 41: 87 - 109.

McKnight, T. L., (1992) Essentials of Physical Geography. Printice Hall, NJ, USA

Minoru Kusakabe, M., Ohsumi, T., and Aramaki, S., (1989). The Lake Nyos gas disaster: chemical and isotopic evidence in waters and dissolved gases from three Cameroonian crater lakes, Nyos, Monoun and Wum. Journal of Volcanology and Geothermal Research, 39(2-3): 167-185

Nesbitt W. W. and Young G. M. (1982) Early Proterozoic climates and plate motions inferred from major element chemistry and lutites. Nature 299, 715-717

Nesbitt, H. W., and Wilson, R. E., (1992). Recent weathering of basalts. American Journal of Science., 292:740 - 777.

Palumbo, B., Angelone, M., Bellanva, A., Dazzi, C., Hauser, S., Neri, S., Wilson, J., (2000). Influence of Inheritance and Pedogenesis on Heavy Metal Distribution in Soils of Sicily, Italy. Geoderma 95: $247-266$.

Sama-Lang P., (2004) Soil and Water Conservation in Banana Production between Mount Cameroon and Bambutus Mountain. 13 ${ }^{\text {th }}$ International Soil Conservation Organisation Conference Brisbane, July 2004. Paper No. 210.

Shaw-Shong, L. (2004). Slope failures. In: Tropical Residual Soils Engineering. Huat et al., (ed) Leiden. Balkema. 71 - 102.

Shi, B., Jiang, H., Liu Z., and Fang H. Y (2005). Engineering geological characteristics of 
expansive soils in China. Engineering Geology $67(1-2) 63-71$

Smithson, P., Addison, K., and Atkinson, K (2002). Fundamentals of the Physical Environment. $3^{\text {rd }}$ Edition. Routledge London.

Suh, C. E., Sparks, R. S. J., Fitton, J. G., Ayonghe, S. N., Annen, C., Nana, R. and Luckman, A,. (2003). The 1999 and 2000 eruptions of Mount Cameroon: eruption behaviour and petrochemistry of lava. Bulletin of Volcanology, 65: $267-281$.

Tan, K. H., 1996. Soil Sampling Preparation and Analysis, Marcel Dekker Inc New York, 392p.

Taylor R. S. and McLennan S. M. (1985). The continental crust: its composition and evolution. Blackwell Scientific, Boston, USA, 312 pp

Tokalioğlu, S., Kartal, S., and Birol, G (2003). Application of a Three-Stage Sequential Extraction Procedure for Determination of Extractable Metal Contents in Highway Soils. Turkish Journal of Chemistry 27: $333-346$.
Tugrul A., Gurpinar, O., (1997). The effects of chemical weathering on the engineering properties of eocene basalts in the northeastern Turkey. Environmental Engineering Geoscience 3: $225-234$.

Tugrul, A., and Gurpinar, O., (1997). The effect of chemical weathering on the engineering properties of Eocene basalts in northeastern Turkey. Environmental and Engineering Geoscience; 3(2): 225-234

Van Reeuwijk, L. P., (1993). Procedures for Soil Analysis, International Soil Reference and Information Centre (ISRIC) Technical paper, no. 9, ISRIC, 19 pp.

Wen, B. P., Duzgoren-Aydin,N. S., and Aydin, A. (2004). Geochemical characteristics of the slip zones of a landslide granitic saprolite, Hong Kong: Implications for their developments and microenvironment. Environmental Geology, 47, $140-154$. 